\title{
Особливості місцевих імунних реакцій у порожній кишці при пострезекційній портальній гіпертензії
}

\begin{abstract}
Мета роботи: дослідити особливості локальних імунних реакцій у порожній кишці при пострезекційній портальній гіпертензії. Матеріали і методи. Дослідження проведено на 45 щурах-самцях, які були розділені на 3 групи: 1-а група - 15 інтактних тварин, 2-а - 15 щурів після резекції лівої бокової частки - 31,5 \% паренхіми печінки, 3-я - 15 тварин після резекції правої та лівої бокових часток печінки (58,1%). Евтаназію тварин здійснювали кровопусканням в умовах тіопентал-натрієвого наркозу через 1 місяць від початку експерименту. Вирізані шматочки із порожньої кишки фіксували в 10 \% нейтральному розчині формаліну і після відповідного проведення через етилові спирти зростаючої концентрації заливали у парафінові блоки. Гістологічні зрізи завтовшки 5-7 мкм після депарафінізації фарбували гематоксилін-еозином, за ван-Гізоном, Маллорі, Вейгертом, толуїдиновим синім. При виявленні плазматичних клітин-продуцентів Ig A, Ig M, Ig G, Ig Е мікротомні зрізи порожньої кишки обробляли моноспецифічними антисироватками проти вказаних класів імуноглобулінів, кон’югованими із ізотіоціанатом флюоресцеїну, застосовуючи прямий метод Кунса з відповідними контролями, які вивчали за допомогою люмінісцентного мікроскопа “Люмам Р-8”. У люмінісцентному світлі рахували плазматичні клітини, що давали специфічне світіння, на 1 мм² слизової оболонки досліджуваного органа. Вміст секреторного Ig A (SIgA) визначали методом роздільної імунодифузії в агарі зі специфічною сироваткою проти SIgA. Кількісні показники обробляли статистично.

Результати досліджень та їх обговорення. Через місяць після резекції 31,5 \% паренхіми печінки локальні імунні реакції у слизовій оболонці порожньої кишки змінювалися незначно. Порушення локального імунного гомеостазу проявилося більш вираженим при резекції 58,1 \% об'єму печінки. Так, число плазматичних клітин з IgA у слизовій оболонці досліджуваного органа зменшилося на 26,6 \%, рівень секреторного імуноглобуліну А знизився на 22,4 \%, а плазмоцити-продуценти IgM, IgG, IgE€, відповідно, збільшилися на 70,1 \%, у 3,8 та 4,6 раза. Ступінь змін місцевого гомеостазу відповідав глибині та поширенню гемодинамічних розладів, дистрофічним, некробіотичним, інфільтративним та склеротичним процесам у досліджуваному органі, тобто йому належить важлива роль у морфогенезі порожньої кишки при пострезекційній портальній гіпертензії. Отже, резекція 58,1 \% паренхіми печінки призводить до пострезекційної портальної гіпертензії та виражених змін локального імунного гомеостазу в слизовій оболонці порожньої кишки, які характеризуються зниженням рівнів SIgA i кількості плазмоцитів-продуцентів IgA, значними порущеннями співвідношень між імуноцитами, що синтезують IgA, IgM, IgG, IgE, появою імунних комплексів у стромі та стінці судин. Ступінь змін місцевих імунних реакцій збігається з глибиною та поширенням гемодинамічних розладів, дистрофічними, некробіотичними, інфільтративними та склеротичними процесами у досліджуваному органі.
\end{abstract}

Ключові слова: пострезекційна портальна гіпертензія; порожня кишка; локальний імунітет.

Постановка проблеми і аналіз останніх досліджень та публікацій. На сьогодні у хірургічних клініках лікувальних закладів нерідко виконують резекцію печінки. Дану операцію здійснюють при доброякісних та злоякісних пухлинах, метастазах, травмах печінки, внутрішньопечінковому холангіолітіазі, альвеолярному ехінококозі, трансплантації печінки $[2,11,12]$. Резекція великих об'ємів паренхіми печінки призводить до виникнення пострезекційної портальної гіпертензії та складних загальнобіологічних процесів, які виникають і розвиваються при цьому в органах і системах організму при його адаптації до нового рівня життєдіяльності $[2,4,13]$. В останні роки дослідники все частіше звертають увагу на зміни місцевого імунітету при різних ушкодженнях тонкої та товстої кишок, зосереджуючи увагу на ролі місцевих імунних реакцій у захисті слизових оболонок від патогенних чинників [5,8]. Варто зазначити, що зміни місцевого імунітету порожньої кишки при резекціях різних об'ємів паренхіми пе- чінки не вивчали, а детальне та об'єктивне знання компенсаторно-адаптаційних процесів у стінці порожньої кишки при резекціях різних об'ємів печінки, їхньої ролі в розвитку ентеральної недостатності до сьогодні досліджені недостатньо і потребують свого вирішення.

Мета роботи: дослідити особливості локальних імунних реакцій у порожній кишці при пострезекційній портальній гіпертензії.

Матеріали і методи. Дослідження проведені на 45 статевозрілих щурах-самцях, які були розділені на 3 групи. 1-а група нараховувала 15 інтактних практично здорових тварин, 2-a - 15 щурів після резекції лівої бокової частки - 31,5 \% паренхіми печінки, 3-я - 15 тварин після резекції правої та лівої бокових часток печінки (58,1%) [4]. Евтаназію дослідних тварин здійснювали кровопусканням в умовах тіопентал-натрієвого наркозу через 1 місяць від початку експерименту. Вирізані шматочки із порожньої кишки фіксували в 10 \% нейтрально- 
му розчині формаліну і після відповідного проведення через етилові спирти зростаючої концентрації заливали у парафінові блоки за загальноприйнятою методикою. Гістологічні зрізи товщиною 5-7 мкм після депарафінізації фарбували гематоксилін-еозином, за ван-Гізоном, Маллорі, Вейгертом, толуїдиновим синім [10]. При виявленні плазматичних клітин-продуцентів IgA, IgM, IgG, IgE мікротомні зрізи порожньої кишки обробляли моноспецифічними антисироватками проти вказаних класів імуноглобулінів, кон'югованими із ізотіоціанатом флюоресцеїну, застосовуючи прямий метод Кунса з відповідними контролями [5,6], які вивчали за допомогою люмінесцентного мікроскопа “Люмам Р-8”. У люмінісцентному світлі підраховували плазматичні клітини, що давали специфічне світіння, на $1 \mathrm{Mm}^{2}$ слизової оболонки досліджуваного органа [5], а також щільність інфільтрату (ЩІ) на 1 мм² тканини кишки, число мастоцитів [1]. Вміст секреторного IgA (SIgA) визначали методом роздільної імунодифузії в агарі зі специфічною сироваткою проти SIgA [8]. Варто вказати, що виконані експериментальні дослідження та евтаназію дослідних тварин проводили із дотриманням “Загальних етичних принципів експериментів на тваринах”, ухвалених Першим національним конгресом з біоетики (Київ, 2001) та відповідно до “Європейської конвенції про захист хребетних тварин, що використовуються в дослідних та інших наукових цілях” [9]. Кількісні показники обробляли статистично. Обробка результатів виконана у відділі системних статистичних досліджень ДВНЗ “Тернопільський державний медичний університет імені І. Я. Горбачевського МОЗ України” в програмному пакеті STATISTIKA (“StatSoft Inc.”, США). Різницю між порівнювальними величинами визначали за критерієм Стьюдента та Манна-Уїтні $[1,7]$.

Результати досліджень та їх обговорення. Отримані дані в результаті проведеного дослідження наведено в таблиці 1. Усестороннім аналі- зом показників, представлених у таблиці 1, встановлено, що через місяць після резекції 31,5 \% паренхіми печінки вони змінювалися незначно. Так, число плазматичних клітин з IgA у слизовій оболонці порожньої кишки зменшилося з 236,5 $\pm 2,1$

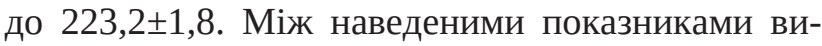
явлено статистично достовірну $(\mathrm{p}<0,01)$ різницю і остання цифрова величина виявилася нижчою від попередньої на 5,6 \%. Кількість плазмоцитів 3 IgM у даних умовах експерименту збільшилася на 4,0 \%, 3 IgG - на 8,3 \%, а з IgE - на 12,6 \%. Концентрація секреторного імуноглобуліну А при цьому 3 статистчно достовірною різницею $(\mathrm{p}<0,01)$ зменшилася $з(0,670 \pm 0,005)$ г/л до $(0,610 \pm 0,006)$ г/л, тобто на 8,9\%.

У дослідних тварин через місяць після резекції 58,1 \% паренхіми печінки при розтині очеревинної порожнини спостерігалося розширення печінкової ворітної вени, повнокрів’я і розширення брижових вен та видимого венозного русла тонкої та товстої кишок. Слизова оболонка порожньої кишки повнокровна, набрякла, з поодинокими осередками точкових крововиливів. Описане вище свідчило про наявність пострезекційної портальної гіпертензії $[4,13]$. Досліджувані локальні імунні реакції у слизовій оболонці порожньої кишки при цьому виявилися більш вираженими порівняно $з$ попередніми. Так, число плазматичних клітин з IgA у слизовій оболонці досліджуваного органа, вираженою статистично достовірною різницею $(\mathrm{p}<0,001)$, зменшилося майже на $28,0 \%$, а плазмоцити-продуценти IgM, IgG, IgE відповідно збільшилися на 70,1 \%, у 3,8 та 4,6 раза.

Рівень секреторного імуноглобуліну А з високим ступенем статистичної достовірності $(\mathrm{p}<0,001)$ зменшився $3(0,670 \pm 0,006)$ до $(0,520 \pm 0,005)$ г/л, тобто на 22,4 \%. Клітинна шільність інфільтрату статистично достовірно $(\mathrm{p}<0,001)$ зросла на 34,0 \%, а кількість мастоцитів - на 28,3 \%. Серед останніх виражено зростала кількість дегранульованих клітин. Відомо, що мастоцити у фазі дегра-

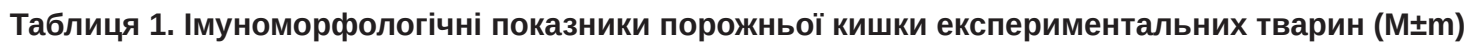

\begin{tabular}{||l|c|c|c||}
\hline \multirow{2}{*}{\multicolumn{1}{|c|}{ Показник }} & \multicolumn{3}{c||}{ Група тварин } \\
\cline { 2 - 4 } & 1 -а & 2 -а & 3 -я \\
\hline Плазматичні клітини 3 IgA & $236,1 \pm 2,1$ & $223,2 \pm 1,8^{* *}$ & $201,2 \pm 1,8^{* * *}$ \\
\hline Плазматичні клітини 3 IgM & $118,3 \pm 1,2$ & $123,1 \pm 1,2^{*}$ & $224,9 \pm 3,3^{* * *}$ \\
\hline Плазматичні клітини 3 IgG & $59,2 \pm 0,6$ & $64,1 \pm 0,7^{* *}$ & $70,80 \pm 0,78^{* * *}$ \\
\hline Плазматичні клітини 3 IgE & $17,40 \pm 0,15$ & $29,60 \pm 0,18^{* * *}$ & $0,520 \pm 0,005^{* * *}$ \\
\hline SIgА, г/л & $0,670 \pm 0,006$ & $0,610 \pm 0,006^{* *}$ & $11036,0 \pm 142,8^{* * *}$ \\
\hline КШІ & $8236,0 \pm 69,6$ & $8710,0 \pm 70,8^{*}$ & $74,8 \pm 0,9^{* * *}$ \\
\hline Мастоцити & $58,3 \pm 0,5$ & $62,4 \pm 0,5^{* *}$ & \\
\hline \hline
\end{tabular}

Примітки: *-p<0,05; **-p<0,01; ***-p<0,001 порівняно з 1-ю групою спостережень. 
нуляції виділяють медіатори (гістамін, серотонін та ін.), забезпечуючи запальну фазу запально-дистрофічних змін у слизових оболонках [3].

Важливою ланкою локального імунного гомеостазу слизових оболонок шлунково-кишкового тракту та дихальних шляхів є SIgA, який забезпечує “першу лінію захисту” вказаних структур від пошкоджувальних агентів. Виражене зниження рівня SIgA при пострезекцій портальній гіпертензії, тобто через місяць після резекції 58,1 \% паренхіми печінки свідчить про значне пошкодження цього імунного захисту. Зростання при цьому плазмоцитів-продуцентів IgM, IgG, IgE, виражене порушення співвідношень між ними вказувало на напруженість та нестабільність локальних імунних реакцій у слизовій оболонці порожньої кишки $[5,6]$.

Необхідно також зазначити, що більшість імунокомпетентних клітин локалізувалася у поверхневих ділянках слизової оболонки порожньої кишки. Серед них зустрічалися Т-лімфоцити, що відповідають за специфічну антигенну стимуляцію, беруть участь в реакціях підвищеної чутливості сповільненого типу, підвищують активність макрофагів шляхом взаємодії 3 попередниками антитілоутворюючих клітин, а також плазмоцити, які виникають з В-лімфоцитів і беруть активну участь в імунних реакціях, завдяки властивості синтезувати білки-імуноглобуліни $[5,6]$. У слизовій оболонці порожньої кишки та ії̈ власній пластинці з'являлися імунні комплекси і дегранульовані тканинні базофіли. Імунні комплекси, а також IgM та IgG фіксувалися у стінках гемокапілярів, кровоносних судин.

При гістологічному дослідженні мікропрепаратів порожньої кишки переважно у 3-й групі спостережень спостерігалися виражені судинні розлади (повнокрів’я переважно венозних судин, явища перивазального набряку, стази у венозній частині мікрогемоциркуляторного русла, осередки діапедезних крововиливів), дистрофічні, некробіотичні зміни епітеліоцитів, ендотеліоцитів,

\section{СПИСОК ЛІТЕРАТУРИ}

1. Автандилов Г. Г. Основы количественной патологической анатомии / Г. Г. Автандилов. - Москва : Медицина, 2002. - 240 с. 2. Вишневский В. А. Сегментарне резекции, отдаленные результаты при злокачественных опухолях печени / В. А. Вишневский, М. Г. Ефанов , И. В. Казаков // Укр. журнал хірургії.-2012. - № 1 (16). - C.5-15.

3. Гасюк Н. В. Цитофункціональна характеристика представництва мастоцитів у яснах хворих на генералізований пародонтит / Н. В. Гасюк, Г. А. Єрошенко, І. О. Іваницький, С. Б. Герасименко // Світ медицини та біології. - 2013. - № 4(41). - C. 66-68. стромальних структур, інфільтративні та склеротичні процеси. Домінували описані патогістологічні зміни у стінці досліджуваного органа через місяць після резекції 58,1 \% паренхіми печінки. Варто також зазначити, що виявлені патогістологічні ушкодження стінки порожньої кишки при резекції печінки збігалися із досліджуваними імуногістологічними показниками. При значних відхиленнях імуногістохімічних параметрів слизової оболонки порожньої кишки від контрольних величин в оболонках досліджуваного органа спостерігалися більш виражені та розповсюджені патогістологічні процеси. Існує думка, що напруженість, нестабільність та виражені зміни імунного захисту слизових оболонок травного тракту призводять до суттєвих порушень тканинного та клітинного структурного гомеостазів [1,6]. Отримані дані свідчать, що локальні імунні процеси відіграють важливу роль у морфогенезі порожньої кишки при тривалій пострезекційній портальній гіпертензії.

Висновки. Резекція 58,1 \% паренхіми печінки призводить до пострезекційної портальної гіпертензії та виражених порушень локального імунного гомеостазу у слизовій оболонці порожньої кишки, які характеризуються зниженням рівнів SIgA і кількості плазмоцитів-продуцентів IgA, значними порущеннями співвідношень між імуноцитами, що синтезують імуноглобуліни IgA, IgM, IgG, IgE, появою імунних комплексів у стромі та стінці судин. Ступінь змін місцевих імунних реакцій збігається із глибиною та поширенням гемодинамічних розладів, дистрофічними, некробіотичними, інфільтративними та склеротичними процесами у досліджуваному органі.

Перспективи подальших досліджень. Всебічне вивчення місцевого імунного гомеостазу порожньої кишки в умовах пострезекційної портальної гіпертензії дозволить суттєво розширити діагностику, корекцію та профілактику досліджуваної патології.

4. Гнатюк М. С. Морфометрична оцінка особливостей ремоделювання структур дванадцятипалої кишки при резекції різних об’ ємів печінки / М. С. Гнатюк, Л. В. Татарчук, О. Б. Ясіновський // Науковий вісник Ужгородського університету. Серія “Медицина”. - 2016. - Вип. 1 (53). - С. 92-95.

5. Головатюк Л. М. Токсичний гепатит як фактор змін локальних імунних реакцій в слизовій оболонці товстої кишки / Л. М. Головатюк, Т. Е. Бондаренко, О. В. Критко // Український журнал медицини, біології та спорту. - 2017. - № 6 (8). - С. 7-11.

6. Кімакович В. Й. Імунна система шлунково-кишкового 
тракту в нормі та патології / В. Й. Кімакович, В. В. Чоп'як, О. В. Бродик. - Тернопіль : Укрмедкнига, 1999. - 100 с.

7. Лапач С. Н. Статистические методы в медико-биологических исследованиях Excell / С. Н. Лапач, А. В. Губенко, П. Н. Бабич. - Киев : Морион, 2001. - 410 с.

8. Мізь А. В. Стан місцевого імунітету у статевозрілих щурів за умов гострої інтоксикації тетрахлоретаном / А. В. Мізь // Здобутки клінічної та експериментальної медицини. - 2012. - № 2(17). - С.194-196.

9. Резников О. Г. Загальні етичні принципи експериментів на тваринах / О. Г. Резников // Ендокринологія. - 2003. - Т. 8, № 1. - C. 142-145.

10. Сорочинников А. Г. Гистологическая и микроскопическая техника / А. Г. Сорочинников, А. Е.Доросевич. - Москва

\section{REFERENCES}

1. Avtadilov, G.G. (2002). Osnovy kolichestvennoy patologicheskoy anatomii [Basis of quantitative pathological anatomy]. Moscow: Meditsina [in Russian].

2.Vishnevskiy, V.A., Yefanov, M.G., \& Kazakov, I.V. (2012). Segmentarnyye rezektsyi, otdalennyye rezultaty pri zlokachestvennykh opukholyakh pecheni [Segmentar resections, longterm results in malignant liver tumors]. Ukr. Zhurnal KhirurhiiUkrainian Journal of Surgery, 1 (16), 5-15 [in Russian].

3. Hasiuk, N.V., Yeroshenko H.A., Ivanytskyy I.O., \& Herasymenko, S.B. (2013). Tsytofunktsionalna kharakterystyka predstavnytstva mastotsytiv u yasnakh khvorykh na heneralizovani parodontyt [Cytoprofunctional characteristic of the representation of mastocytes in the gums of patients with generalized periodontitis].Svit medytsyny ta biolohiyi - The World of Medicine and Biology, 4(41), 66-68 [in Ukrainian].

4. Hnatiuk, M.S., Tatarchuk, L.V. Yasinovskyi, O.B. (2016). Morpfometrychna otsinka osoblyvostei remodeliuvania struktur dvanadtsiatypaloi kyshky pry resektsii riznykh obiemiv pechinky [Morphometric evaluation of the features of remodeling of duodenal structures at resection of different volumes of the liver]. Naukovyi visnyk Uzhhorodskoho universytetu. Seriia "Medytsyna" - Scientific Herald of Uzhhorod University. Series "Medicine", 1 (49), 3-5 [in Ukrainian].

5. Holovatiuk, L.M., Bondarenko, T.E., \& Krytko, O.V. (2017). Toksychnyi hepatyt yak faktor zmin lokalnykh imunnykh reaktsii $\mathrm{v}$ slyzovii obolontsi tovstoi kyshky [Toxic hepatitis as a factor of changes in local immune reactions in the mucous membrane of the colon]. Ukrainskyi zhurnal medytsyny, biolohii ta sportu - Ukrainian Journal of Medicine, Biology and Sports, 6 (8), 7-11 [in Ukrainian]. 6. Kimakovych, V.Y., Chopiak, V.V., \& Brodyk, O.V. (1999).
: Медицина, 2007. -448 с.

11. Nakajima K. Efficacy of the predicted operation time strategy for syndronous colorectal liver metastasis feasibility study for staged resection in patients in long predicted operation time / K. Nakajima, S. Takanashi, N. Saito // Gastrointest. Surg. - 2013. - Vol. 17, No. 4. - P. 688-695.

12. Reddy S. S. From child-pugh to model for end-stage liver disease: Deciding who needs a liver transplant / S. S. Reddy, J. M. Civan // Med. Clin. Noth. Am. - 2016. - Vol. 100, No. 3. P. 449-464.

13. Sawada K. Multiple portal hypertensive polyps of the jejunum accompanied by anemia of the unknown origin / K. Sawada, T. Ohtake, N. Veno // Gastrointest. Endosc. - 2011. - Vol. 73. - P. 179-182.
Imunna systema shlunkovo-kyshkovoho traktu v normi ta patolohii [Immune system gastrointestinal tract in normal and pathology]. Ternopil: Ukrmedknyha [in Ukrainian].

7. Lapach, S.N., Hubenko, A.V., \& Babych, P.N. (2001). Statistichiskiye metody $v$ mediko-biologicheskikh issledovaniyakh Excell [Statistical methods in medicobiological investigations Excell]. Kyiv: Morion [in Ukrainian].

8. Miz, A.V. (2012) Stan mistsevoho imunitetu u statevozrilykh shchuriv za umov hostroi intoksykatsii tetrakhloretanom [The condition of local immunity in sexually mature rats in conditions of acute intoxication with tetrachlorethanom]. Zdobutky klinichnoi ta eksperymentalnoi medytsyny - The Achievements of Clinical and Experimental Medicine, 2 (17), 194-196 [in Ukrainian].

9. Reznikov, O.H. (2003). Zahalni etychni pryntsypy eksperymentiv na tvarynakh [General ethical principles of experiments on animals]. Endokrynolohiia - Endocrinology, 8, 1, 142-145 [in Ukrainian].

10. Sorochinnikov, A.G., \& Dorosevich, A.Ye. (2007). Gistologichieskaya i mikroskopicheskaya tiekhnika. [Histological and microscopic equipments]. Moscow: Meditsina [in Russian]. 11. Nakajima, K., Takanashi, S., \& Saito, N. (2013). Efficacy of the predicted operation time strategy for syndronous colorectal liver metastasis feasibility study for staged resection in patients in long predicted operation time. Gastrointest. Surg., 17, 4, 688-695. 12. Reddy, S.S., \& Civan, J.M. (2016). From child-pugh to model for end-stage liver disease: Deciding who needs a liver transplant. Med. Clin. Noth. Am., 100 (3), 449-464.

13. Sawada, K., Ohtake, T., \& Veno, N. (2011). Multiple portal hypertensive polyps of the jejunum accompanied by anemia of the unknown origin. Gastrointest., Endosc., 73, 179-182.

\section{V. TATARCHUK}

I. Horbachevsky Ternopil State Medical University

\section{PECULIARITIES OF LOCAL IMMUNE REACTIONS INJJJUNUM AT POSTRESECTION PORTAL HYPERTENSION}

The aim of the work: to investigate the features of local immune reactions in the jejunum at postresection portal hypertension. Materials and Methods. The research was conducted on 45 male rats, which were divided into 3 groups. The group 1 consisted of 15 intact animals, 2-15 rats after resection of the left lateral part - 31.5\% of liver parenchyma, 3-15 animals after resection of the right and left side parts of the liver (58.1\%). Euthanasia of animals was carried out by bloodletting in conditions of thiopental anesthesia 1 
month after the beginning of the experiment. The cut pieces of the jejunum were fixed in a $10 \%$ neutral formalin solution, and after appropriate ethyl alcohol of increasing concentration was poured in paraffin blocks. Histologic sections 5-7 mm thick after deparaffinization were stained with hematoxylin-eosin, for van Gizon, Mallory, Weigert, and toluidine blue. In the detection of plasmocytes with IgA, IgM, IgG, IgE histologic sections of the jejunum was treated with monospecific antiserum against these classes of immunoglobulins conjugated with fluorescein isothiocyanate using the direct Kuns method with appropriate controls that were studied using a luminescent microscope "Lumam P-8". In a luminescent light, plasmatic cells that gave a specific luminescence were read on $1 \mathrm{mmI}$ of the mucosa of the investigated organ. The content of secretory Ig A (SIgA) was determined by the method of separate immunodiffusion in agar with a specific serum against SIgA. Quantitative indicators were processed statistically.

Results and Discussion. One month after resection of $31.5 \%$ of the liver, local immune reactions in the mucosa of the jejunum changed slightly. Violation of local immune homeostasis was more pronounced in resection of $58.1 \%$ of the liver parenchima. Thus, the number of plasmatic cells with IgA in the mucosa of the subject decreased by $26.6 \%$, the level of secretory immunoglobulin A decreased by $27.9 \%$, while the plasmocytes producers IgM, IgG, IgE increased accordingly by $70.1 \%, 3.8$ and 4.6 times. The degree of changes in local homeostasis correlated with the depth and prevalence of hemodynamic disorders, dystrophic, fibrotic, infiltrative and sclerotic processes in the investigated organ, that is, it plays an important role in the morphogenesis of the jejunum at postresection portal hypertension. Accordingly, resection of $58.1 \%$ of liver parenchyma leads to postresection portal hypertension and pronounced changes in local immune homeostasis in the jejunum mucosa, characterized by a decrease in the levels of SIgA and the number of IgA-producing plasmocytes, significant violations of the relation between the immunocytes that synthesize IgA, IgM, IgG, IgE, the emergence of immune complexes in the stroma and wall of vessels. The degree of changes in local immune homeostasis correlates with the depth and prevalence of hemodynamic disorders, dystrophic, fibrotic, infiltrative and sclerotic processes in the investigated organ.

Key words: postresection portal hypertension; jejunum; local immunity.

\section{Л. В. ТАТАРЧУК}

ГВУз “Тернопольский государственный медицинский университет имени И. Я. Горбачевского МЗ Украины”

\section{ОСОБЕННОСТИ МЕСТНЫХ ИМУННЫХ РЕАКЦИЙ В ТОЩЕЙ КИШКЕ ПРИ ПОСТРЕЗЕКЦИОННОЙ ПОРТАЛЬНОЙ ГИПЕРТЕНЗИИ}

Цель работы: исследовать особенности локальных имунных реакций в тощей кишке при пострезекционной портальной гипертензии.

Материалы и методы. Исследования проведены на 45 крысах-самцах, которые были разделены на 3 группы. 1-я группа состояла из 15 интактных животных, 2-я - 15 крыс после резекции левой боковой части - 31,5 \% паренхимы печени, 3-я - 15 животных после резекции правой и левой боковых частей печени (58,1%). Эвтаназия животных осуществлялась кровопусканием в условиях тиопентал-натриевого наркоза через 1 месяц от начала эксперимента. Вырезанные кусочки из тощей кишки фиксировали у 10 \% нейтральном растворе формалина и после соответствующего проведення через этиловые спирты возростающей концентрации заливали у парафиновые блоки. Гистологические срезы толщиной 5-7 мкм после депарафинизации красили гематоксилинэозином, по ван-Гизону, Маллори, Вейгерту, толуидиновым синим. При виявлении плазматических клеток-продуцентов Ig A, Ig M, Ig G, Ig E микротомные срезы тощей кишки обрабатывали моноспецифическими антисыроватками против указанных класов иммуноглобулинов, конъюгированными из изотиоцианатом флюоресцеина, применяя прямой метод Кунса из соответствующими контролями, которые изучали с помощью люминисцентного микроскопа “Люмам Р-8”. У люминисцентном свете подсчитывали плазматические клетки, что специфически светились, на 1 мм² слизистой оболочки исследуемого органа. Содержание секреторного Ig A (SIgA) определяли методом раздельной иммунодиффузии в агаре из специфической сыроваткою против SIgA. Количественные показатели обрабатывали статистически.

Результаты исследований и их обсуждение. Через месяц после резекции 31,5 \% паренхимы печени локальные имунные реакции у слизистой оболочке тощей кишки изменялись незначительно. Нарушения локального имунного гомеостаза оказалось более выраженным при резекции 58,1 \% объема печени. Число плазматических клеток с IgA в слизистой оболочке исследуемого органа при этом уменьшилось на 29,5 \%, уровень секреторного имуноглобулина А снизился на 22,4 \%, а плазмоцитыпродуценты IgM, IgG, IgE соответственно увеличились на 79,1 \%, в 3,8 и 4,6 раза. Степень изменений местного имунного гомеостаза соответстовал глубине и выраженности гемодинамических расстройств, дистрофическим, некробиотическим, инфильтративным и склеротическим процессам в исследуемом органе, то есть, ему принадлежит важная роль у морфогенезе тощей кишки при пострезекционной портальной гипертензии. Таким образом, полученные результаты свидетельствуют, что резекция 58,1 \% паренхимы печени приводит к пострезекционной портальной гипертензии и выраженным изменениям локального имунного гомеостаза в слизистой оболочке тощей кишки, которые характеризируются снижением уровней SIgA и количества плазмоцитов-продуцентов IgA, значительными нарушениями соотношений между имуноцитами, что синтезируют IgA, IgM, IgG, $\operatorname{IgE}$, появлением имунных комплексов в строме и стенке сосудов. Степень изменений местных имунных реакций совпадает с глубиной и распространением гемодинамических расстройств, дистрофическими, некробиотическими, инфильтративными и склеротическими процессами в исследуемом органе.

Ключевые слова: пострезекционная портальная гипертензия; тощая кишка; локальный имуннитет. 